Article

\title{
Sustainable Public Procurement: The Impact of Ability, Motivation, and Opportunity on the Implementation of Different Types of Sustainable Public Procurement
}

\author{
Jolien Grandia ${ }^{1, *(\mathbb{D})}$ and Dylan Voncken ${ }^{2}$ \\ 1 Department of Public Administration and Sociology, Erasmus School of Social and Behavioural Sciences, \\ Erasmus University Rotterdam, 3062 PA Rotterdam, The Netherlands \\ 2 Department Organisation \& Personnel, Ministry of Finance, 2500 EE The Hague, The Netherlands; \\ d.j.p.voncken@minfin.nl \\ * Correspondence: grandia@essb.eur.nl
}

Received: 1 August 2019; Accepted: 17 September 2019; Published: 24 September 2019

check for updates

\begin{abstract}
Public organisations develop sustainable public procurement (SPP) policies to compel suppliers to contribute to societal goals. Studies show that the ability, motivation, and opportunity that procurers have to procure in a sustainable manner affect the uptake of SPP. Most studies into SPP examine these factors only in the context of one type of SPP (e.g., green procurement). The goal of this paper is therefore to examine the relationship between ability, motivation, and opportunity and six types of SPP: (1) green public procurement, (2) social return on investment, (3) circular economy, (4) bio-based public procurement, (5) innovation-oriented public procurement and (6) international social criteria. An online survey was administered amongst procurers working in Dutch public organisations. The research shows that ability, motivation, and opportunity affect Green Public Procurement (GPP). Opportunity did affect green public procurement, innovation-oriented public procurement and circular economy, but not the other types of SPP. We were unable to identify an antecedent of more social types of SPP in this research. This research shows that findings based on GPP cannot be directly generalized to other types of SPP, and that there is a need for research into the antecedents of social types of SPP.
\end{abstract}

Keywords: sustainable public procurement; sustainability; ability; motivation; opportunity; green public procurement; survey

\section{Introduction}

Around the world, public organisations have designed sustainable public procurement (SPP) policies to oblige suppliers to contribute to the achievement of their policy objectives [1,2]. Public procurement refers to the acquisition of goods and services by government or public sector organisations [3]. In the European Union, public organisations annually spend approximately $16 \%$ of the gross domestic product on public procurement [4], and it is increasingly used as policy tool [5]. In the Netherlands, public procurement is for example used to stimulate the production and consumption of environmentally friendly products, diminish the distance to the labour market for the long-term unemployed, and drive innovation [6]. The uptake and implementation of these SPP policies are the topic of a growing number of academic studies [7]. They show that the uptake and implementation of SPP varies greatly across countries, organisations, and projects [8,9]. One explanation for this is that inside the public organisations, changes have to be made and barriers removed, which does not always happen [10]. Grandia, for example, showed that public procurers that 
are not affectively motivated to SPP, implement fewer SPP than public procurers that are affectively motivated [10]. Knowledge is also frequently identified as a barrier or driver of SPP. Due to the complexity and contested nature of sustainability a lack of knowledge makes it difficult for public procurers to see the potential of SPP, which drives them to make safe and traditional choices [8,11-14], and which as such can enable or disable procurers from procuring sustainably. Other studies explain that public procurers also need to have the opportunity to procure in a sustainable manner. Walker and Brammer [8], for example, explain that it helps if procurers work in an organisation with a climate that is supportive of change and doing something new.

Although we know from extant studies that the ability, motivation and opportunity to procure in a sustainable manner affect the implementation of SPP, the majority of these studies examined it only in the context of one type of SPP; for example, only in the context of green public procurement (GPP) [9,15], but not in the context of social procurement, fair trade or circular economy. SPP is considered to be an umbrella concept that encompasses "a concern for social, economic and environmental aspects of procurement decisions" [16]. Public organisations have thus developed SPP policies that, for example, aim to reduce the environmental impact of production and consumption (green public procurement or GPP), but also policies that aim to reduce the employability chances for the long-term unemployed (social return on investment or SROI), that drive innovation (IPP) or that reduce waste and work toward a more circular economy (CIE). Although the literature has thus identified ability, motivation, and opportunity as barriers and drivers of SPP, we do not know if the barriers and drivers for all types of SPP are the same because it only examined these factors in regards to specific types of SPP. The goal of this paper is therefore to examine the effect of ability, motivation, and opportunity on the implementation of six types of SPP policies in the Dutch public sector. More information about the types of SPP is presented in Section 2.

The following research question has therefore been formulated: If and how do the perceived ability, motivation, and opportunity to procure in a sustainable manner affect the implementation of the various types of SPP? To answer this question, a survey was administered amongst Dutch public procurers. The Netherlands is considered a frontrunner with regards to SPP [17] and has developed and implemented a wide range of SPP policies [6]; it is therefore considered an ideal context for examining the impact of various barriers on the various types of SPP. In the next section of the paper the factors that will be examined are presented and discussed in more detail, followed by a methodology section, the presentation of the findings, a discussion and the conclusions.

\section{Research Background}

In 2005, the Dutch national government accepted a motion in the House of Representatives to use their annual spending power to stimulate the market for sustainable goods and services, and to act as a role model. As a result, a policy on environmentally friendly procurement for the national, local and provincial government was developed and implemented. Since then, sustainable public procurement has grown into a multidimensional policy in the Netherlands, encompassing policies on (1) Green Public Procurement (GPP), (2) Bio-based Public Procurement (BPP), (3) International Social Criteria (ISC), (4) Social Return On Investment (SROI), as well as (5) Innovation-oriented Public Procurement (IPP) and (6) Circular Economy (CIE) [6].

First, the policy on Green Public Procurement (GPP) is aimed at preventing or minimising the negative impact of production and consumption on the natural environment. The GPP policy encompasses a wide range of environmental criteria for groups of products that public organisations frequently procure (e.g., office equipment, uniforms, road works, catering), which must be applied when procuring from these categories [18]. In addition to these compulsory environmental criteria, the policy lists some wishes that the government wishes public procurers to consider in their procurement projects, but that are not compulsory [18].

Second, the policy on bio-based public procurement (BPP) prescribes the inclusion of natural and renewable materials in the procurement of goods, services, and works. By increasing the demand 
for bio-based products through their own purchases, the government wants to ensure that more bio-based products are produced and that new bio-based products can be developed and can drive the development of a bio-based economy [19].

Third, the policy on International Social Criteria (ISC) aims to contribute to the elimination of unfair trade throughout the international supply chain, and to eliminate, for example, child labour, inhumane working conditions, and starvation wages [20].

Fourth, the policy on Social Return On Investment (SROI) encompasses an approach that aims to increase the employment opportunities for people at a distance from the labour market (e.g., due to long-term unemployment, a partial incapacity to work, or a disability) by encouraging or obliging contractors to include opportunities for people at a distance from the labour market in the execution of the contract [21].

Fifth, with the policy on Innovation-oriented Public Procurement (IPP), the Dutch national government wants to stimulate the market to come up with innovative and unique solutions to better perform via their procurement or to directly procure innovative solutions [22].

Sixth, with the policy on Circular Economy (CIE), the Dutch government aims to make suppliers responsible for closing the lifecycle loop and to ensure that materials are not wasted at the end of their lifecycle, thereby contributing to the transition to a circular economy. In a circular economy, there is no linear system with waste at the end of the lifecycle, but rather materials are reused without losing value [23].

Each of these sustainable public procurement policies has their own initiators, designers, policy briefs, and implementation. For example, the GPP policy is a compulsory nation-wide policy and is implemented in phases in a wide range of public organisations, including municipalities, water boards and provinces, unlike the SROI policy, which is not compulsory for all organisations. In general, all policies aim to make public procurement more sustainable and to use procurement to reach desired outcomes in society; together, they fall under the umbrella concept of SPP.

\section{Theoretical Framework}

Existing studies offer a wide range of concepts and definitions related to sustainable developments in the context of procurement and purchasing [24], such as green public procurement [25-27], sustainable public procurement $[9,28-31]$, green purchasing [32,33], sustainable supply chain management [24,34-36], environmentally friendly supply chain management [37], environmentally responsible public procurement [38], green procurement behaviour [39] or sustainable procurement behaviour $[9,11]$. These concepts sometimes describe the same developments (e.g., green public procurement and environmentally friendly procurement) and sometimes different phenomena (e.g., sustainable public procurement and sustainable supply chain management). In this study we examine SPP, which can be viewed as part of the broader concept of sustainable supply chain management (SSCM) [24], since several parts of the supply chain can be made more sustainable via procurement. SPP encompasses the integration of a concern for social and economic impacts in the procurement by public organisations [16,40]. Meehan and Bryde [13] describe SPP as "the acquisition of goods and services in a way that ensures that there is the least impact on society and the environment throughout the full life cycle of the product". This is much in line with the European Commission's [41] definition of SPP as "a process by which public authorities seek to achieve the appropriate balance between the three pillars of sustainable development-economic, social and environmental—when procuring goods, services or works at all stages of the project". In line with these definitions $[13,16,40,41]$, SPP can be viewed as an umbrella concept, encompassing policies on both social and environmental procurement. SPP thus encompasses green public procurement (GPP) but is not synonymous with GPP.

Prior research into GPP and SPP often focuses on the identification of factors that influence their implementation $[8,10,42-45]$. Many studies identified structural factors that act as drivers or barriers, such as rules and regulations, budgets or the financial viability of sustainable alternatives $[8,37,42,46]$. However, studies also show that the characteristics of the people involved in the procurement project, 
as well the organisation they are working in, affect the implementation of sustainable procurement. Grandia [10] found that individual level factors, such as commitment or ability, had the strongest impact on the implementation of GPP. Being willing and able to procure in a sustainable or environmentally friendly manner has been found to increase the implementation of both SPP and GPP. For example, Testa, Iraldo, Frey, and Daddi [47], found knowledge and expertise to be important in SPP; procurers have to be aware of sustainable procurement practices and have the knowledge to apply relevant rules and regulations. Furthermore, Brammer and Walker [16] found that organisational incentives play a role in the implementation of SPP. Yang, Su, Wang and Hua [39] found that the stronger the ability to control their own resources was, the more willing they were to implement green procurement. Grandia $[10,43]$ concluded that affective commitment to change increases the implementation of GPP. If a public procurer truly identified with green public procurement and it was in line with their own personal vision, the implementation of GPP increased. The more people are motivated to procure in a green manner, the more they are likely to actually do so (and thus perform better with regard to sustainable procurement).

In the procurement and purchasing literature, relatively little is known about the role that these individual level factors play in procurers' performance in implementing new procurement initiatives, such as GPP and SPP. In the HRM literature, however, the relationship between employee behaviour and performance has been examined extensively and systematically. We therefore used insights from the field of HRM to examine how context factors could affect the performance of public procurers with regard to SPP. Within the HRM field, the AMO framework of Boxall and Purcell [48] is frequently used. It identifies ability, motivation, and opportunity as determinants of employee performance [48]. The AMO framework has been tested in numerous studies and shows that a well-trained and skilled employee will be able perform better and that a motivated worker will be willing to "go the extra mile", but that if the work environment does not provide adequate opportunities the employees' abilities and motivation will be meaningless [49]. In short, employees have to be able, motivated and have the opportunity to actually do something; if they do not then it becomes incredibly hard to do it. We assume a similar mechanism can be found in the implementation of sustainable public procurement. In this research, we will therefore use the AMO framework to research the impact of procurers' abilities, motivation and opportunities on the implementation of various types of SPP.

Ability is operationalised in this study as the skills and knowledge that procurers perceive to have about sustainability. Sustainability in general and SPP in particular are considered complex concepts, requiring specific knowledge and skills. Both knowledge and skills have been identified as important drivers or conditions for the implementation of SPP and particularly GPP [9,10,50,51]. Knowledge of SPP practices has thus already been found to play an important role in the implementation of GPP [9], but whether this also applies for the other types of SPP and if the same holds true for skills related to SPP is not yet known. Skills have been mentioned as being important for the implementation of SPP, but their impact has not yet been tested. The first hypotheses are therefore:

Hypothesis 1 (H1). Knowledge about sustainability and SPP has a positive effect on the implementation of all types of SPP.

Hypothesis 2 (H2). Skills related to sustainability and SPP have a positive effect on the implementation of all types of SPP.

Motivation is operationalised in this research as affective commitment to SPP. Several studies indicate that if procurers are motivated or committed to implement a SPP policy, they are more likely to implement it $[37,52,53]$. Affective commitment to SPP refers to the desire to show support for SPP based on an inherent belief in the benefits of SPP, and thus not out of peer pressure or fear of repercussions [9-11]. It has already been positively linked to the implementation of GPP [9-11], but has not yet been examined in relationship to other types of SPP. The third hypothesis is therefore: 
Hypothesis 3 (H3). Affective commitment to SPP has a positive effect on the implementation of all types of $S P P$.

Opportunity refers to the opportunity a procurer has to include SPP in their procurement projects. As stated earlier, the procurement process is a decision-making process where the decisions of the procurer to, for example, look up additional information about sustainability can result in more SPP $[9,10]$. However, they have to be in an environment that is conducive to searching for more information and that is open to doing something with the results. Procurers therefore have to work in an organisation that is open to new ideas and to learning something new. Walker and Brammer [8], for example, found that the degree to which the prevailing climate in an organisation is supportive of change affects the development of sustainable procurement. Opportunity has therefore been operationalised as the organisational learning capacity. The organisational learning capability consists of the organisational and managerial characteristics that foster the organisational propensity to learn, and it encompasses five dimensions: experimentation, risk taking, interaction with the external environment, dialogue, and participative decision-making [54]. Although the organisational learning capacity has not been examined in relationship to sustainable procurement, is has been found to increase an organisation's general innovativeness and performance. As all types of SPP require the organisation to change its procurement practices and do something new, the fourth hypothesis is therefore:

Hypothesis 4 (H4). The organisational learning capacity has a positive effect on the implementation of all types of SPP.

In the conceptual model (see Figure 1), the four hypotheses of the study are illustrated. It shows that we hypothesize that ability (knowledge and skills), motivation (affective commitment to change) and opportunity (organisational learning capacity) have a positive influence on the implementation of six types of SPP: GPP, ISC, SROI, BPP, CIE and IPP. In the next section, we will discuss the methodology behind the research and testing the hypotheses.

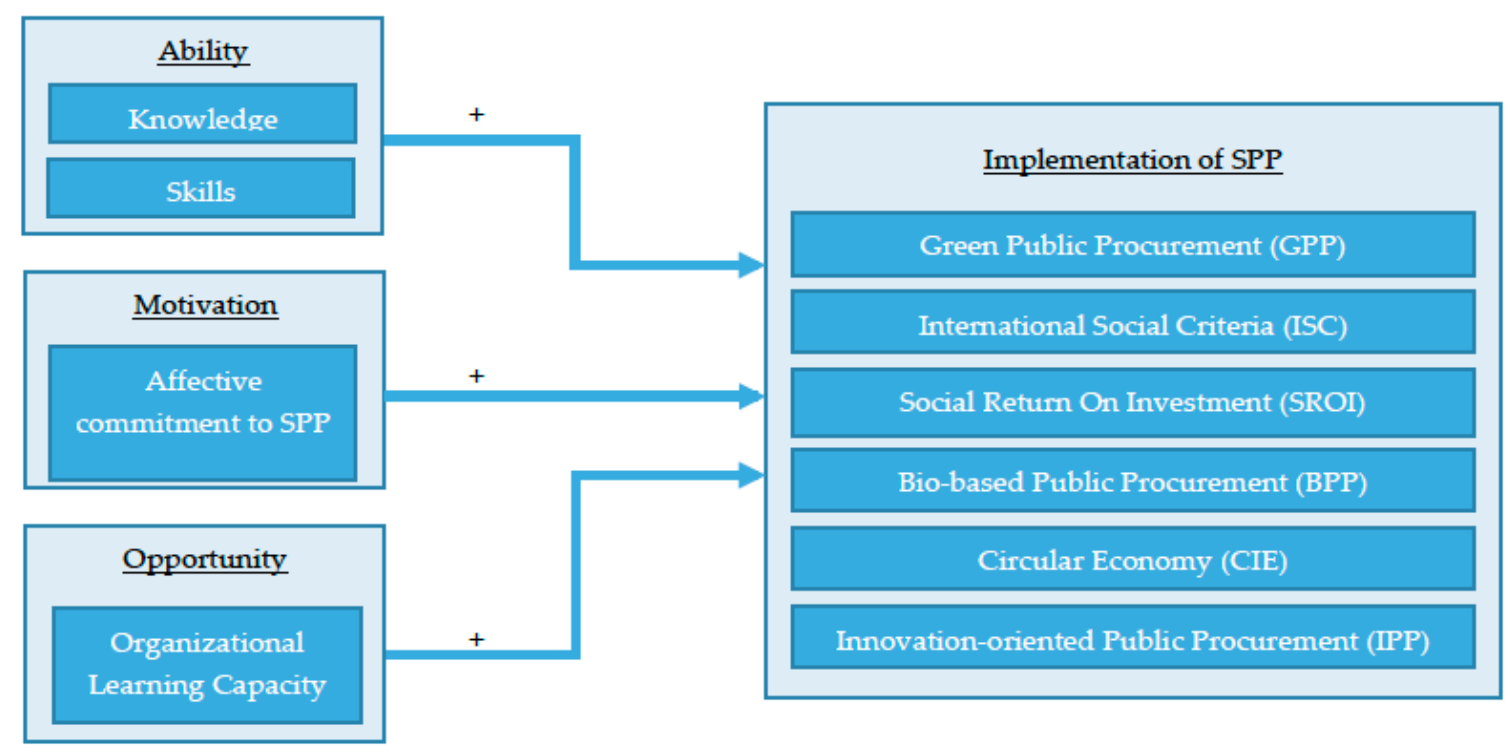

Figure 1. Conceptual model. 


\section{Methodology}

\subsection{Sampling}

In the spring of 2016, the subscribers to the newsletters of two Dutch associations that provide expertise and training for (public) procurers received an invitation to participate in the online survey. These two associations were selected because they form the main source of training and information for public procurers in the Netherlands. These organisations are well known by professionals working in the field of public procurement, who are likely to be on their mailing list. The first association is the only organisation in the Netherlands that offers certified procurement training programmes. In addition, they organize a wide range of workshops, conferences, and activities for procurers in both the public and private sector. The second association is a public procurement expertise centre paid for by the Dutch national government. They aim to bring together information about public procurement and provide public procurers with useful tools via their websites, workshops, meetings, and annual conference. The subscribers to the newsletters of these two associations therefore offer a valid sample of public procurement professionals in the Netherlands.

Given that the research is about the ability, motivation, and opportunity of public procurers to implement SPP, only newsletter recipients that, according to the information in the CRM database, worked in the Dutch public sector, had a procurement related job, an active e-mail and received the regular newsletters from both organisations, received an invitation e-mail, thereby for example excluding procurers working in the private sector, as well as consultants and researchers who work in the field of public procurement but who are not themselves involved in the actual procurement process. Respondents who were subscribers to the newsletters of both associations received only one invitation. The survey was built online using the Qualtrix software. Every respondent received a personalized invitation to participate in the survey. In this invitation e-mail all respondents were informed about the purpose of the study and guaranteed anonymity.

The invitation e-mail was sent to all recipients on 14 April 2016, followed by a first reminder via e-mail on 26 April 2016 and a second reminder via e-mail on 12 May 2016. In addition, the survey was mentioned in the associations' newsletters, their websites, and on social media.

\subsection{Measures}

This section describes the measures that were used in this study. Both the SPP knowledge and SPP skills were measured using a reversed single-item question from Grandia [10] that measured the procurers' perceived insufficiency of knowledge regarding GPP. The question was reversed to "I have enough knowledge to professionally procure sustainably" to increase the fit with the other questions. This question was also rephrased into "I have enough skills to professionally procure sustainably" to measure the perceived degree of skills. The items were both measured on a five-point Likert scale, ranging from completely disagree to completely agree.

Affective commitment to change was measured using the eight-item scale developed by Herscovitch and Meyer [55]. This scale has been used very frequently, and its robustness has been proven [56], including in the context of measuring the commitment to SPP [10]. The scale has six items that are measured on a five-point Likert scale, ranging from completely disagree to completely agree. Two items were phrased negatively and were reversed prior to the analysis. The following two items were reversed: "I think that the management is going in the wrong direction by implementing $S P P$ " and " $m y$ organisation's procurement is better off without SPP". The scale has a Cronbach Alpha of 0.876 .

The perceived organisational learning capacity of the organisations was measured using the scale by Chiva, Alegre and Lapiedra [54]. The scale has been validated in other studies and found to be robust. The scale consists of 14 items related to idea development, room for risk taking, as well as interaction with the environment, communication, and participation in decision-making. An example of an item is "people here receive support and are encouraged to present new ideas" or "employees are encouraged to communicate". The items are measured on a five-point Likert scale, ranging from completely disagree 
to completely agree. OLC is an organisational-level construct, unlike the other variables. However, like Camps, Oltra, Aldás-Manzano, Buenaventura-Vera, and Torres-Carballo [57], we chose to measure it on an individual level. As Camps et al. [57] explained, this also fits the scale's original proposal, as Chiva et al. [54] intended that individuals in organisations would fill out the form and evaluate the OLC level. While there is an increasing amount of (multilevel) studies that aggregate individual level perceptions to the level of the organisation, for our study it does not matter if individual employees agree about the level of OLC. We are interested in testing if employees perceive that there is a high level of OLC and whether that affects the perceived implementation of the various types of SPP. We have therefore opted not to conduct a multilevel study. While the original scale by Chiva et al. [54] consisted of five components, a direct Oblimin factor analysis found only three components in our study. Each component has a total Eigen value of more than one. A Kaiser-Meyer-Olkin (KMO) test showed that the data is suitable for a factor analysis (0.873) [58]. Component 1 consists of the seven items related to room for idea development, risk, and interaction with the environment. This component is from now on called Organisational Learning Capacity for Ideas, Risk, and Interaction (OLCIRI). Component 2 consists of four items and overlaps exactly with Chiva et al.'s [54] subscale regarding communication and sharing knowledge in the organisation. This component is thus from now on called Organisational Learning Capacity for Communication and Knowledge Sharing (OLCCKS). Component three consist of three items and overlaps exactly with Chiva et al.'s [54] subscale about involvement and participation. It is from now on called Organisational Learning Capacity for Involvement and Participation (OLCIP). For each individual subscale, the Cronbach alpha was calculated: OLCIRI (0.830), OLCCKS (0.864), and OLCIP (0.893).

For measuring the implementation of the various types of SPP, an adapted version of the single-item for the degree of SPP was used [9]. Each type of SPP (GPP, SROI, IPP, BPP, ISC and CIE) was measured separately, but the items were introduced with the following introduction: "The following question is about the implementation of specific sustainable public procurement types in your actual procurement project. Please indicate per type how often you actually applied them in your procurement projects". A five-point Likert-type scale was used, ranging from never to always. As in the Netherlands SPP is an umbrella concept that encompasses multiple policies, a factor analysis (direct Oblimin) was conducted to test whether the different policies do indeed fit together. The factor analysis showed that that all types of SPP did indeed form one component. The KMO was 0.803 , and the single component scored an Eigen value of $>1$. The Cronbach Alpha was acceptable but not great with 0.791. In the SEM, we therefore opted to analyse the individual types of SPP rather than the SPP scale, and to correlate the error terms; this also allowed us to research the impact of the independent variables on all types of SPP.

In addition, the following control variables were included in the survey: year of birth and gender. The year of birth was measured on a scale ranging from 1940 to 2000. The gender (male/female) was coded as a dummy variable (Supplementary Materials). 


\subsection{Data Analysis}

The hypotheses were tested using structural equations modelling (SEM) with IBM AMOS 26. SEM is a second-generation multivariate technique that has significant advantages over first-generation techniques such as multiple regression; specifically, SEM allows researchers to test relationships among multiple predictor and criterion variables, to model errors in measurements for observed variables, and to conduct confirmatory analyses [59]. In short, SEM allowed us to test the entire conceptual model in one analysis, and to examine the relationship between ability, motivation and opportunities and the different types of SPP at the same time. With SEM, the overall fit of the model was determined using a combination of absolute and relative fit indices [60]: specifically, two absolute fit indices: the chi-square "goodness of fit test" (CMIN/DF), and the root mean squared error of approximation (RMSEA) [60,61]. An SMRM and RMSEA value equal to or below 0.08 and a non-significant chi-square value with a CMIN/DF value below 2.0 indicate that the model has an acceptable model fit [60-64]. Additionally, three relative fit indices were checked: the Tucker-Lewis Index (TLI), comparative fit index (CFI) and a goodness of fit index (GFI). The threshold value for all three relative fit indices for a good model fit is greater than 0.9 [63]. As our final measurement model includes the mediation effects, a bootstrapping method was also employed via AMOS [65]. In the bootstrapping method, 5000 samples (with replacement) were created for the available observed sample. Via these samples, the significance of the indirect relations was calculated. The descriptive statistics and basic inferential statistics were calculated with IBM SPSS Statistics version 25.

As the data is self-reported and collected amongst a single group, it could be subject to a common method bias [66]; to rule this out, a Harman one-factor was carried out on all the items used to measure the hypotheses to see if the majority of the variance could be explained by a single factor $[67,68]$. Together, the components accounted for $71.9 \%$ of the variance, and no single component was accountable for more than $28.4 \%$ of the variance. As no single factor emerged from the factor analysis and common method, variance could therefore be ruled out.

In Table 1, the bivariate correlation, means, and standard deviations are presented. The results show that GPP has the most frequent application, with a mean of 3.676, directly followed by SROI (3.578), scoring well above the theoretical mean. However, even the least frequently reported type of SPP, BBPP, scores barely below the theoretical mean (2.242). 
Table 1. Correlations, means and standard deviation.

\begin{tabular}{|c|c|c|c|c|c|c|c|c|c|c|c|c|c|c|c|c|}
\hline & $\mathbf{M}$ & SD & 1 & 2 & 3 & 4 & 6 & 7 & 8 & 9 & 10 & 11 & 12 & 13 & 14 & 15 \\
\hline $\begin{array}{l}\text { 1. Organisational Learning Capacity for } \\
\text { Ideas, Risk, and Interaction }\end{array}$ & 2.881 & 0.70706 & 1 & & & & & & & & & & & & & \\
\hline $\begin{array}{l}\text { 2. Organisational Learning Capacity for } \\
\text { Involvement and Participation }\end{array}$ & 2.8746 & 0.86381 & $0.490^{* *}$ & 1 & & & & & & & & & & & & \\
\hline $\begin{array}{l}\text { 3. Organisational Learning Capacity for } \\
\text { Communication and Knowledge Sharing }\end{array}$ & 3.5 & 0.78208 & $0.617^{* *}$ & $0.517^{\text {** }}$ & 1 & & & & & & & & & & & \\
\hline 4. Affective commitment to change & 4.0042 & 0.7023 & $0.185^{* *}$ & 0.078 & 0.073 & 1 & & & & & & & & & & \\
\hline 5. Green public procurement & 3.676 & 1.2359 & $0.253 * *$ & $0.196^{* *}$ & 0.170 * & $0.214^{* *}$ & 1 & & & & & & & & & \\
\hline 6. Biobased public procurement & 2.242 & 1.6865 & 0.059 & -0.082 & -0.03 & 0.004 & $0.337^{* *}$ & 1 & & & & & & & & \\
\hline 7. Circular Economy & 2.316 & 1.5587 & $0.197^{* *}$ & 0.063 & 0.119 & 0.034 & 0.440 ** & $0.654^{* *}$ & 1 & & & & & & & \\
\hline 8. Social Return on Investment & 3.578 & 1.4452 & 0.113 & 0.028 & -0.028 & 0.023 & $0.328^{* *}$ & 0.256 ** & $0.285^{* *}$ & 1 & & & & & & \\
\hline 9. International Social Criteria & 2.858 & 1.855 & 0.134 & 0.061 & -0.002 & 0.017 & $0.299 * *$ & $0.570^{* *}$ & $0.472^{* *}$ & $0.316^{* *}$ & 1 & & & & & \\
\hline $\begin{array}{l}\text { 10. Innovation-oriented public } \\
\text { procurement }\end{array}$ & 2.907 & 1.2252 & $0.281^{* *}$ & 0.061 & $0.165^{*}$ & 0.048 & $0.353 * *$ & $0.479 * *$ & $0.541^{* *}$ & $0.224 * *$ & $0.278^{* *}$ & 1 & & & & \\
\hline 11. Knowledge & 3.034 & 1.0305 & $0.230 * *$ & 0.124 & 0.096 & $0.301 * *$ & $0.208 * *$ & 0.062 & 0.104 & -0.018 & 0.12 & 0.133 & 1 & & & \\
\hline 12. Skills & 3.126 & 1.0114 & $0.243 * *$ & 0.123 & $0.239 * *$ & $0.246 * *$ & $0.204^{* *}$ & 0.056 & 0.107 & 0.028 & 0.092 & $0.138 *$ & $0.778^{* *}$ & 1 & & \\
\hline 13. Gender & 0.233 & 0.4227 & -0.048 & -0.087 & -0.057 & 0.056 & 0.061 & 0.035 & -0.025 & 0.002 & -0.007 & -0.025 & 0.04 & 0.013 & 1 & \\
\hline 14. Birth year & 1965.789 & 9.1704 & -0.032 & 0.029 & 0.001 & -0.036 & -0.084 & -0.111 & -0.129 & -0.07 & $-0.219 * *$ & -0.074 & 0.087 & 0.067 & $0.286^{* *}$ & 1 \\
\hline
\end{tabular}




\section{Results}

\subsection{Descriptive Statistics}

On average procurers reported a very high degree of affective commitment to SPP (4.0042), and a relatively average degree of knowledge (3.034) and skills (3.126). Of the three factors of OLC, OLCIRI and OLCIP have an almost identical mean (2.881 and 2.874), with OLCCKS being slightly higher (3.5). The respondents' average year of birth is 1965 , which made them on average 51 when the survey was administered. There is, however, a rather high standard deviation of 9.17.

As expected, affective commitment to SPP $\left(0.214^{* *}\right)$, OLCIRI $\left(0.253^{* *}\right)$, OLCIP $\left(0.196^{* *}\right)$, OLCCKS $\left(0.170^{*}\right)$, knowledge $\left(0.208^{* *}\right)$ and skills $\left(0.204^{* *}\right)$ all correlate positively with GPP. However, this does not hold true for the other types of SPP. BBPP and SROI do not correlate significantly with any of the independent variables, circular economy only correlates significantly with OLCIRI $\left(0.197^{* *}\right)$, and IPP only correlates significantly with OLCIRI $\left(0.281^{* *}\right)$, OLCCKS $\left(0.165^{*}\right)$ and skills $\left(0.138^{*}\right)$. Of the control variables, the gender does not correlate significantly with any of the variables, and interestingly the year of birth correlates significantly negatively with international social criteria (ISC). The correlation table thus shows that the various types of SPP are not related to the same variables, indicating that we should be careful in generalising findings about GPP to other types of SPP.

\subsection{Structural Equation Modelling}

Although our sample is above the advised threshold of 200 for using SEM [60], our number of variables was too large to use latent variables for our sample size, as indicated by too many degrees of freedom compared to our sample size. The minimum ratio between the degrees of freedom and the sample size is 5:1 [69]. However, others claim that if the ratio falls below 10:1 the results and trustworthiness of the research is already questionable [60]. The SEM analysis was therefore carried out in AMOS using the composite scale developed in SPSS for affective commitment to change and the three components of OLC. The three components of OLC (OLCIRI, OLCIP, and OLCCCKS) were treated as observed variables belonging to the unobserved variable OLC in the SEM analysis. The final ratio of the degrees of freedom and the sample size was 7:1, which is an acceptable ratio.

As stated earlier, the overall fit of the models was measured using a combination of absolute and relative fit indices [60]: relative chi square (CMIN/DF), a goodness of fit index (GFI), a comparative fit index (CFI), a root mean square error of approximation (RMSEA) and the $p$ of Close Fit (PClose).

The original model, including the two control variables (gender and year of birth), did not have acceptable fit indices. To reach a good fitting model, several insignificant relations between the variables were removed from the model. The variables BBPP, SROI, and Skills were removed from the model, as they had no significant relationships to any of the variables. For the same reason, the control variable gender was also removed. To further improve the model fit, the modification indices and expected parameter change values were examined. Based on this and theoretical reasoning, error term correlations were added for the different types of SPP [70]. After examining the modification indices and theoretical reasoning, it also became apparent that knowledge and affective commitment to SPP partially mediated the relationship between OLC and GPP.

The revised and final model is presented in Figure 2; only the significant relations $(<0.05)$ are shown. The model provided an adequate fit to the data (see also Table 2). The model had the following scores on the relative and absolute fit indices: $\mathrm{CMIN} / \mathrm{DF}=1.143, \mathrm{GFI}=0.987, \mathrm{CFI}=0.992, \mathrm{RMSEA}=$ 0.022 , and PClose $=0.814$. The final model shows that OLC has a positive and significant direct effect on GPP $\left(\beta=0.23^{* *}\right)$, IPP $\left(\beta=0.24^{* *}\right)$ and CIE $\left(\beta=0.15^{*}\right)$. Thus, the more public procurers perceive that their organisation has an organisational learning capacity, the more they implement GPP, IPP, and CIE. Interestingly, more OLC does not result in more BPP or SROI. 


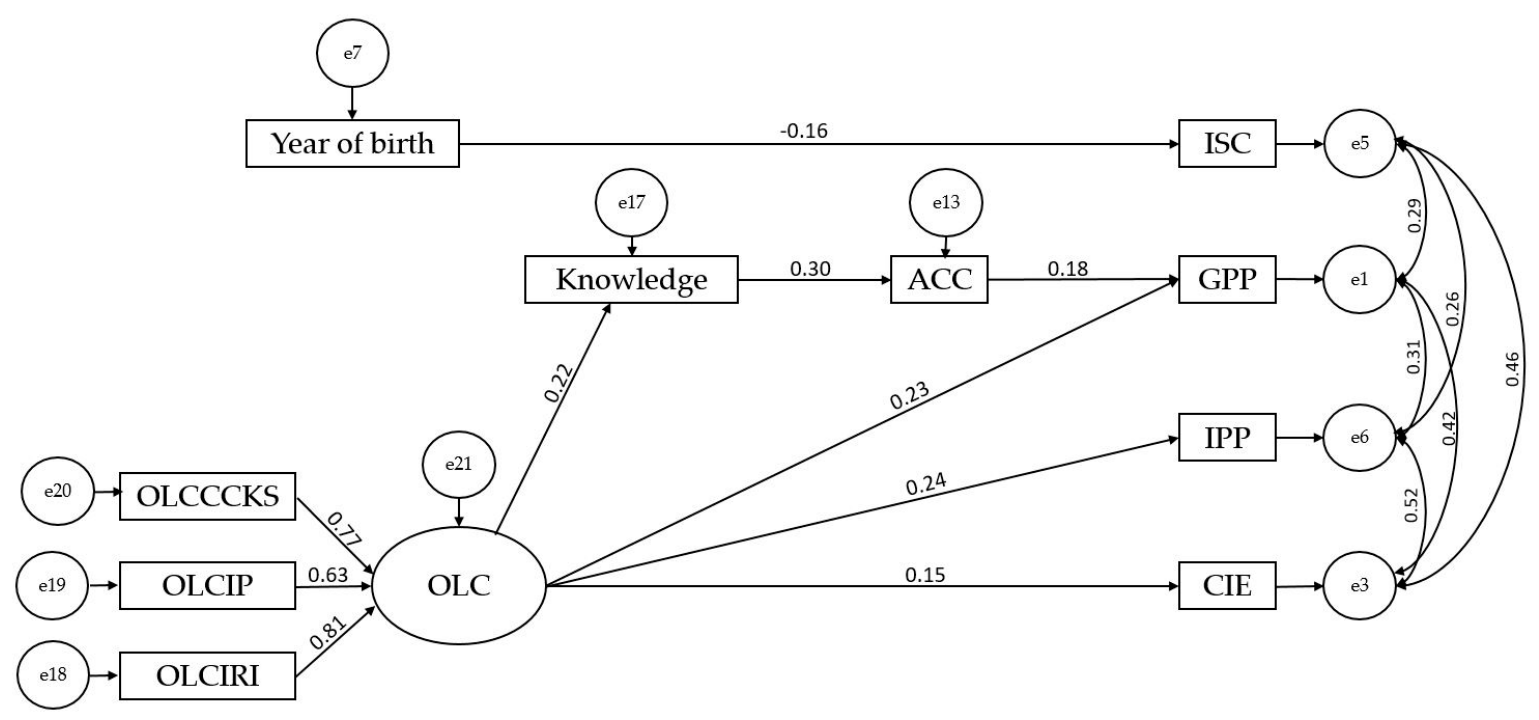

Figure 2. The results of the SEM analysis.

Table 2. Goodness of fit tests for the model.

\begin{tabular}{cccccc}
\hline & CMIN/df & RMSEA & CFI & TLI & GFI \\
\hline Final model & 1.143 & 0.022 & 0.992 & 0.974 & 0.987 \\
Fit criteria good fit & $\leq 2.00$ & $<0.08$ & $>0.9$ & $>0.9$ & $>0.9$ \\
\hline
\end{tabular}

The final model also shows that OLC also indirectly increases the implementation of GPP, via knowledge and ACC (affective commitment to SPP). OLC has a positive effect on the perceived degree of knowledge about SPP $(\beta=0.22 * *)$, which in turn has a positive effect on the degree of affective commitment to SPP $\left(\beta=0.30^{* * *}\right)$, which then has a positive effect on the implementation of SPP $\left(\beta=0.18^{* *}\right)$. A bootstrap analysis via AMOS [65] showed that the indirect relationship between OLC and GPP via knowledge and affective commitment to SPP was also significant ( $p$ value of 0.014 ). The relationship between knowledge and GPP, mediated by ACC, is also significant ( $p$ value $=0.002$ ), as is the relationship between OLC and ACC that is mediated by knowledge ( $p$ value 0.018].

\section{Discussion}

In this part of the paper we discuss the findings in relation to the literature, the limitations of the study, as well as implications for both future research and practice.

First, as opposed to our first two hypotheses, the ability (knowledge and skills) to procure in a sustainable manner did not have a positive effect on all types of SPP. The perceived degrees of skills related to SPP did not have a significant effect (positive or negative) on any of the SPP types. Having the skills to professionally procure in a sustainable manner might thus be important, but it will not increase the perceived degree of any type of SPP. A high perceived degree of knowledge also did not have a direct effect on any of the SPP types. It did, however, have an indirect effect on GPP, via affective commitment to SPP. Affective commitment to SPP (or motivation) fully mediated the relationship between knowledge and GPP. This means that the more a procurer feels that they have enough knowledge about sustainability, the more they are affectively committed to implementing it, which results in more implementation of GPP. This contrasts with an earlier finding of Grandia [9], who found that both knowledge about SPP and affective commitment had an indirect impact on GPP (via sustainable procurement behaviour), but that they were unrelated to each other. The relationship between knowledge, affective commitment to change and GPP thus requires further research. The finding that knowledge is only (albeit indirectly) related to GPP and none of the other types of SPP does show that implementing these types of SPP might require other abilities than knowledge. 
These abilities, that do play a role in the implementation of the other types of SPP, thus also require further research.

Second, as opposed to our third hypothesis, motivation (affective commitment to SPP) also did not have a significant positive effect on the various types of SPP. As mentioned earlier, it only had a significant effect on GPP, but not on any of the other types of SPP. The finding that affective commitment to SPP has a positive influence on the degree of GPP corroborates the finding of Grandia [9], but also shows that the antecedents of GPP are not the same as the antecedents of the other types of SPP. Being affectively committed to SPP, and thus being personally convinced of the necessity of SPP, does have a positive effect on the implementation of GPP but not on the other types of SPP. Organisations looking to increase the implementation of various types of SPP cannot therefore simply administer a "one-size-fits-all" approach, given that what might drive the implementation of GPP does nothing for the SROI of CIE. This finding thus clearly highlights the necessity to research the implementation of the various types of SPP and to not only focus on the implementation of GPP. This also shows that it is crucial for scholars to provide clear operationalisations of their concepts, and that in future studies, SPP and GPP should not be used interchangeably. They are distinct concepts, which requires them to be studied as such.

Third, our fourth hypothesis was that the more opportunities there are for public procurers to procure in a sustainable manner, the more they will do this. We therefore measured the degree of organisation learning capacity that the respondents perceived in their organisation, encompassing for example the degree that the organisation supports the development of new ideas, information sharing or involves employees in big decisions. The results show that the three dimensions of OLC (OLCIRI, OLCCKS, and OLCIP) had a significant and positive effect on GPP, CIE and IPP. The fourth hypothesis is thus proven for GPP, CIE and IPP, but disproven for SROI, BPP and ISC. The finding that OLC had a significant and positive effect on IPP is not surprising, as OLC has already been found to have a significant impact on the attitude toward the organisational adoption of knowledge-intensive innovations [71]. However, it is interesting to see that an organisation that is open to learning does not affect all types of SPP, but only GPP, CIE and IPP, and that the two social types of SPP (ISC and SROI) are not affected by it. This could mean that for these types of SPP, organisations do not need to learn as much but would perhaps respond more to stringent rules and regulations.

Overall, our study corroborated earlier findings but also showed that these findings cannot be generalized to other types of SPP. With the exception of the second hypothesis (which was disproven for every type of SPP), all other hypotheses were proven in the case of some types of SPP and disproven in the case of other types of SPP. What affects GPP is vastly different from what affects ISC or BPP. We therefore recommend, for public organisations that are looking to increase the implementation of SPP, to look for made-to-measure approaches. They cannot assume that what worked for the implementation of GPP will also work for the implementation of CIE or BPP. This study, however, does learn that having an organisation that is open and conducive to learning, and where there is thus a lot of OLC, will have a significant effect on the implementation of GPP, IPP and CIE. As OLC has also been found to improve the overall employee performance [57,72], we recommend public organisations to invest in improving their OLC and, specifically, to check whether their employees perceive that there is a high degree of OLC.

It also interesting to see that the two social types of SPP that we measured (SROI and ISC) are not affected by any of the abilities, opportunities, or motivations we measured. This means that a more inherent belief in the benefits, more knowledge, or an organisation conducive to learning have no significant effect in the implementation of these social types of SPP, and that they might have completely different antecedents and require a completely different approach. Overall, this shows that the multidimensionality of SPP requires a multidimensional and made-to-measure approach, which needs further research to identify the antecedents of all types of SPP. 


\section{Limitations and Suggestions for Further Research}

As any study, our study is not without its limitations. The first limitation is related to the limited scope of the research; only procurers working in Dutch public organisations were surveyed. We therefore have to be careful about generalizing the findings to public procurers working in other countries or to private procurers. Moreover, the Netherlands is considered to be a front-runner with regards to SPP [17], which could mean that the antecedents differ compared to countries that are lagging more behind. It would however be interesting to see if the identified antecedents of the various types of SPP follow a similar pattern for procurers working in other countries or contexts.

Second, we only surveyed public procurers that are subscribers to the newsletters of procurement associations. Although these organisations are considered to be the sources of information for practitioners in the Netherlands, there might be public procurers that were not in their database. We thus have to be careful about generalizing the findings.

Third, in the study we examined the role of knowledge, skills, affective commitment to change, and the organisational learning capacity on the various types of SPP, as determinants of the ability, motivation, and opportunity. However, other variables also of course affect the ability, motivation, and opportunity to procure in a sustainable manner. For example, only one type of commitment to SPP has been measured, affective commitment to SPP, while there are three different kinds of commitment to SPP [10]. As the affective commitment to SPP was only found to influence GPP and none of the other types of SPP, it would be interesting to see if commitment fueled out of something else than a personal conviction, such as peer pressure or fear for penalties, does influence the implementation of the other types of SPP.

Fourth, in this study we only measured the perceived degree of the different variables, including the implementation of SPP. We thus only know how frequently public procurers think they implemented GPP or chose IPP, but not if this is actually how often they paid attention to this. More research using the actual procurement data is therefore necessary.

\section{Conclusions}

In this final section of the paper, we present an answer to the main research question. The main research question was: Do the perceived ability, motivation, and opportunity to procure in a sustainable manner affect the implementation of the various types of SPP? To answer this question, a survey was administered amongst Dutch public procurers, measuring the impact of ability (knowledge and skills), motivation (affective commitment to SPP), and opportunity (organisational learning capacity) on various types of SPP (GPP, ISC, CIE, BBPP, IPP and SROI).

In short, the answer to the research question is no, it does not. Although the various types of SPP did correlate with each other, the different types of SPP are distinct from each other; furthermore, the SEM analysis showed that each type of SPP has its own unique antecedents. This refers to ability (operationalised as knowledge and skills), knowledge and any (albeit an indirect) relationship to GPP, but not to any of the other types of SPP. Skills had no significant relationship with any type of SPP. Motivation (operationalised as affective commitment) did affect GPP, but none of the others types of SPP. Opportunity had an influence on most types of SPP, as there is a direct relationship between opportunity (operationalised as OLC), and GPP, IPP and CIE. We thus conclude that ability, motivation, and opportunity affect GPP but not all types of SPP. We were unable to identify an antecedent for more social types of SPP in this research. This conclusion highlights the importance of a clear operationalisation of the different types of SPP, and therefore that findings based on GPP cannot be directly generalized to other types of SPP. Moreover, it highlights the overall need for further research into the antecedents of social types of SPP.

Supplementary Materials: The following are available online at http://www.mdpi.com/2071-1050/11/19/5215/s1. 
Author Contributions: Conceptualization, J.G. and D.V.; Formal analysis, J.G. and D.V.; Investigation, D.V.; Methodology, J.G. and D.V.; Project administration, D.V.; Supervision, J.G.; Writing-original draft, J.G.; Writing-review \& editing, J.G.

Funding: The data was collected during a paid internship of the second author at PIANOo (an expertise centre for public procurement). The research itself however did not receive funding.

Acknowledgments: The authors wish to thank NEVI and PIANOo for allowing them to administer the survey amongst the subscribers of their newsletters and the three anonymous reviewers for their comments.

Conflicts of Interest: The authors declare no conflict of interest. The internship organisation (PIANOo) was not involved in the design of the study or data collection, analyses, or interpretation of data; in the writing of the manuscript, or in the decision to publish the results.

\section{References}

1. Rolfstam, M. Public procurement as an innovation policy tool: The role of institutions. Sci. Public Policy 2009, 36, 349-360. [CrossRef]

2. Moore, M.H. Creating Public Value: Strategic Management in Government; Harvard University Press: Cambridge, MA, USA; London, UK, 1995; p. 416.

3. Uyarra, E.; Flanagan, K. Understanding the Innovation Impacts of Public Procurement. Eur. Plan. Stud. 2010, 18, 123-143. [CrossRef]

4. European Commission. Public Procurement. Available online: http://ec.europa.eu/trade/policy/accessingmarkets/public-procurement/ (accessed on 29 July 2019).

5. Grandia, J.; Meehan, J. Public procurement as a policy tool: Using procurement to reach desired outcomes in society. Int. J. Public Sect. Manag. 2017, 30, 302-309. [CrossRef]

6. PIANOo MVI-Thema's. Available online: http://www.pianoo.nl/themas/maatschappelijk-verantwoordinkopen-duurzaam-inkopen/mvi-thema-s (accessed on 29 July 2019).

7. Ongaro, E. Public Procurement in Europe; Public Administration and Public Management in Europe; Palgrave MacMillan: London, UK, 2017; pp. 363-380.

8. Walker, H.; Brammer, S. Sustainable procurement in the United Kingdom public sector. Supply Chain Manag. Int. J. 2009, 14, 128-137. [CrossRef]

9. Grandia, J. Finding the missing link: Examining the mediating role of sustainable public procurement behaviour. J. Clean. Prod. 2016, 124, 183-190. [CrossRef]

10. Grandia, J. Implementing Sustainable Public Procurement: An Organisational Change Perspective; Erasmus University Rotterdam: Rotterdam, The Netherlands, 2015.

11. Grandia, J.; Steijn, B.; Kuipers, B. It is not easy being green: Increasing sustainable public procurement behaviour. Innovation 2015, 28, 243-260. [CrossRef]

12. Bowen, F.E.; Cousins, P.D.; Lamming, R.C.; Faruk, A.C. The role of supply management capabilities in green supply. Prod. Oper. Manag. 2001, 10, 174-189. [CrossRef]

13. Meehan, J.; Bryde, D. Sustainable procurement practice. Bus. Strategy Environ. 2011, 20, 94-106. [CrossRef]

14. Chan, E.S.; Hon, A.H.; Chan, W.; Okumus, F. What drives employees' intentions to implement green practices in hotels? The role of knowledge, awareness, concern and ecological behaviour. Int. J. Hosp. Manag. 2014, 40, 20-28. [CrossRef]

15. Testa, F.; Annunziata, E.; Iraldo, F.; Frey, M. Drawbacks and opportunities of green public procurement: An effective tool for sustainable production. J. Clean. Prod. 2014. [CrossRef]

16. Brammer, S.; Walker, H. Sustainable procurement in the public sector: An international comparative study. Int. J. Oper. Prod. Manage. 2011, 31, 452-476. [CrossRef]

17. Renda, A.; Pelkmans, J.; Egenhofer, C.; Schrefler, L.; Luchetta, G.; Selçuki, C.; Ballesteros, J.; Zirnhelt, A. The Uptake of Green Public Procurement in the EU27. 2012. Available online: https://ec.europa.eu/environment/ gpp/pdf/CEPS-CoE-GPP\%20MAIN\%20REPORT.pdf (accessed on 23 September 2019).

18. PIANOo Milieuvriendelijk Inkopen. Available online: https://www.pianoo.nl/nl/themas/maatschappelijkverantwoord-inkopen-mvi-duurzaam-inkopen/mvi-thema-s/milieuvriendelijk-inkopen (accessed on 29 July 2019).

19. PIANOo Biobased Inkopen. Available online: https://www.pianoo.nl/nl/themas/maatschappelijkverantwoord-inkopen-mvi-duurzaam-inkopen/mvi-thema-s/biobased-inkopen (accessed on 29 July 2019). 
20. PIANOo Internationale Sociale Voorwaarden Toegelicht. Available online: https://www.pianoo.nl/nl/themas/ maatschappelijk-verantwoord-inkopen-duurzaam-inkopen/mvi-themas/internationale-sociale-4 (accessed on 29 July 2019).

21. PIANOo Social Return. Available online: https://www.pianoo.nl/nl/themas/maatschappelijk-verantwoordinkopen-mvi-duurzaam-inkopen/mvi-thema-s/social-return (accessed on 29 July 2019).

22. PIANOo Innovatiegericht Inkopen. Available online: https://www.pianoo.nl/nl/themas/innovatiegerichtinkopen (accessed on 29 July 2019).

23. PIANOo Circulair Inkopen. Available online: https://www.pianoo.nl/nl/themas/maatschappelijkverantwoord-inkopen-duurzaam-inkopen/mvi-themas/circulair-inkopenn (accessed on 29 July 2019).

24. Amann, M.K.; Roehrich, J.; Eßig, M.; Harland, C. Driving sustainable supply chain management in the public sector: The importance of public procurement in the European Union. Supply Chain Manag. 2014, 19, 351-366. [CrossRef]

25. Cheng, W.; Appolloni, A.; D’Amato, A.; Zhu, Q. Green Public Procurement, missing concepts and future trends-A critical review. J. Clean. Prod. 2018, 176, 770-784. [CrossRef]

26. Palmujoki, A.; Parikka-Alhola, K.; Ekroos, A. Green public procurement: Analysis on the use of environmental criteria in contracts. Rev. Eur. Community Int. Environ. Law 2010, 19, 250-262. [CrossRef]

27. Tarantini, M.; Loprieno, A.D.; Porta, P.L. A life cycle approach to Green Public Procurement of building materials and elements: A case study on windows. Energy 2011, 36, 2473-2482. [CrossRef]

28. Melissen, F.; Reinders, H. A reflection on the Dutch Sustainable Public Procurement Programme. J. Integr. Environ. Sci. 2012, 9, 27-36. [CrossRef]

29. Flynn, A.; Davis, P.; McKevitt, D.; McEvoy, E. Sustainable Public Procurement in Practice: Case Study Evidence from Ireland; PrAcademic Press: Boca Raton, FL, USA, 2013.

30. Oruezabala, G.; Rico, J. The impact of sustainable public procurement on supplier management-The case of French public hospitals. Ind. Mark. Manag. 2012, 41, 573-580. [CrossRef]

31. Bernal, R.; San-Jose, L.; Retolaza, J.L. Improvement Actions for a More Social and Sustainable Public Procurement: A Delphi Analysis. Sustainability 2019, 11, 4069. [CrossRef]

32. Green, K.; Morton, B.; New, S. Green purchasing and supply policies: Do they improve companies' environmental performance? Supply Chain Manag. 1998, 3, 89-95. [CrossRef]

33. Murray, J.G. Effects of a green purchasing strategy: The case of Belfast City Council. Supply Chain Manag. 2000, 5, 37-44. [CrossRef]

34. Carter, C.R.; Rogers, D.S. A framework of sustainable supply chain management: Moving toward new theory. Int. J. Phys. Distrib. Logist. Manag. 2008, 38, 360-387. [CrossRef]

35. Gold, S.; Seuring, S.; Beske, P. Sustainable Supply Chain Management and Inter-Organizational Resources: A Literature Review. Corp. Soc. Responsib. Environ. Manag. 2010, 17, 230-245. [CrossRef]

36. Grosvold, J.U.; Hoejmose, S.K.; Roehrich, J. Squaring the circle: Management, measurement and performance of sustainability in supply chains. Supply Chain Manag. 2014, 19, 292-305. [CrossRef]

37. Walker, H.; Di Sisto, L.; McBain, D. Drivers and barriers to environmental supply chain management practices: Lessons from the public and private sectors. J. Purch. Supply Manag. 2008, 14, 69-85. [CrossRef]

38. Li, L.; Geiser, K. Environmentally responsible public procurement (ERPP) and its implications for integrated product policy (IPP). J. Clean. Prod. 2005, 13, 705-715. [CrossRef]

39. Yang, S.; Su, Y.; Wang, W.; Hua, K. Research on Developers' Green Procurement Behavior Based on the Theory of Planned Behavior. Sustainability 2019, 11, 2949. [CrossRef]

40. Preuss, L. Addressing sustainable development through public procurement: The case of local government. Supply Chain Manag. 2009, 14, 213-223. [CrossRef]

41. European Commission. Green and Sustainable Public Procurement. Available online: http://ec.europa.eu/ environment/gpp/versus_en.htm (accessed on 29 July 2019).

42. Giunipero, L.C.; Hooker, R.E.; Denslow, D. Purchasing and supply management sustainability: Drivers and barriers. J. Purch. Supply Manag. 2012, 18, 258-269. [CrossRef]

43. Grandia, J.; Groeneveld, S.M.; Kuipers, B.S.; Steijn, A.J. Sustainable Procurement in Practice: Explaining the Degree of Sustainable Procurement from an Organizational Perspective. In Public Procurement's Place in the World: The Charge Towards Sustainability and Innovation; Decarolis, F., Frey, M., Eds.; Palgrave Macmillan: Basingstoke, UK, 2014; pp. 37-62. 
44. Günther, E.; Scheibe, L. The hurdle analysis. A self-evaluation tool for municipalities to identify, analyse and overcome hurdles to green procurement. Corp. Soc. Responsib. Environ. Manag. 2006, 13, 61-77. [CrossRef]

45. Varnas, A.; Balfors, B.; Faith-Ell, C. Environmental consideration in procurement of construction contracts: Current practice, problems and opportunities in green procurement in the Swedish construction industry. J. Clean. Prod. 2009, 17, 1214-1222. [CrossRef]

46. McMurray, A.J.; Islam, M.M.; Siwar, C.; Fien, J. Sustainable procurement in Malaysian organizations: Practices, barriers and opportunities. J. Purch. Supply Manag. 2014, 20, 195-207. [CrossRef]

47. Testa, F.; Iraldo, F.; Frey, M.; Daddi, T. What factors influence the uptake of GPP (green public procurement) practices? New evidence from an Italian survey. Ecol. Econ. 2012, 82, 88-96. [CrossRef]

48. Boxall, P.; Purcell, J. Strategy and Human Resource Management, 3rd ed.; Palgrave Macmillan: Basingstoke, UK, 2011; p. 408.

49. Marin-Garcia, J.A.; Tomas, J.M. Deconstructing AMO framework: A systematic review. Intang. Cap. 2016, 12, 1040-1087. [CrossRef]

50. Walker, H.L.; Gough, S.; Bakker, E.F.; Knight, L.A.; McBain, D. Greening operations management: An online sustainable procurement course for practitioners. J. Manag. Educ. 2009, 33, 348-371. [CrossRef]

51. Igarashi, M.; Boer, L.; Michelsen, O. Investigating the anatomy of supplier selection in green public procurement. J. Clean. Prod. 2015, 108, 442-450. [CrossRef]

52. Ageron, B.; Gunasekaran, A.; Spalanzani, A. Sustainable supply management: An empirical study. Int. J. Prod. Econ. 2011, 140, 168-182. [CrossRef]

53. Erridge, A.; Hennigan, S. Sustainable procurement in health and social care in Northern Ireland. Public Money Manag. 2012, 32, 363-370. [CrossRef]

54. Chiva, R.; Alegre, J.; Lapiedra, R. Measuring organisational learning capability among the workforce. Int. J. Manpow. 2007, 28, 224-242. [CrossRef]

55. Herscovitch, L.; Meyer, J.P. Commitment to organizational change: Extension of a three-component model. J. Appl. Psychol. 2002, 87, 474-487. [CrossRef]

56. Choi, M. Employees' attitudes toward organizational change: A literature review. Hum. Resour. Manag. 2011, 50, 479-500. [CrossRef]

57. Camps, J.; Oltra, V.; Aldás-Manzano, J.; Buenaventura-Vera, G.; Torres-Carballo, F. Individual performance in turbulent environments: The role of organizational learning capability and employee flexibility. Hum. Resour. Manag. 2016, 55, 363-383. [CrossRef]

58. Hutcheson, G.D.; Sofroniou, N. The Multivariate Social Scientist: Introductory Statistics Using Generalized Linear Models; Sage: London, UK, 1999; p. 288.

59. Chin, W.W. Commentary: Issues and Opinion on Structural Equation Modeling. MIS Q. 1998, 22, vii-xvi.

60. Kline, R.B. Principles and Practice of Structural Equation Modeling, 4th ed.; Guilford Press: New York, NY, USA, 2011; p. 534.

61. Brown, T.A. Confirmatory Factor Analysis for Applied Research, 2nd ed.; Methodology in the Social Sciences; Guilford Publications: New York, NY, USA, 2014; p. 462.

62. Anderson, J.C.; Gerbing, D.W. Structural equation modeling in practice: A review and recommended two-step approach. Psychol. Bull. 1988, 103, 411. [CrossRef]

63. Hu, L.; Bentler, P.M. Cutoff criteria for fit indexes in covariance structure analysis: Conventional criteria versus new alternatives. Struct. Equ. Model. 1999, 6, 1-55. [CrossRef]

64. Bentler, P.M. Comparative fit indexes in structural models. Psychol. Bull. 1990, 107, 238. [CrossRef] [PubMed]

65. Hayes, A.F. Beyond Baron and Kenny: Statistical mediation analysis in the new millennium. Commun. Monogr. 2009, 76, 408-420. [CrossRef]

66. Meier, K.J.; O'Toole, L.J. Subjective organizational performance and measurement error: Common source bias and spurious relationships. J. Public Adm. Res. Theory 2013, 23, 429-456. [CrossRef]

67. Podsakoff, P.M.; Organ, D.W. Self-reports in organizational research: Problems and prospects. J. Manag. 1986, 12, 531-544. [CrossRef]

68. Podsakoff, P.M.; MacKenzie, S.B.; Lee, J.; Podsakoff, N.P. Common method biases in behavioral research: A critical review of the literature and recommended remedies. J. Appl. Psychol. 2003, 88, 879. [CrossRef]

69. Bentler, P.M.; Chou, C. Practical issues in structural modeling. Sociol. Methods Res. 1987, 16, 78-117. [CrossRef] 


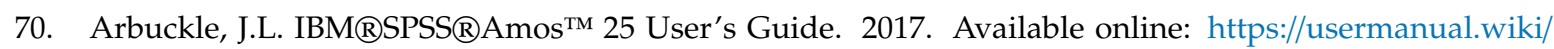
Document/IBMSPSSAmosUserGuide.308874530/view (accessed on 23 September 2019).

71. Teo, H.; Wang, X.; Wei, K.; Sia, C.; Lee, M.K. Organizational learning capacity and attitude toward complex technological innovations: An empirical study. J. Am. Soc. Inf. Sci. Technol. 2006, 57, 264-279. [CrossRef]

72. Rose, R.C.; Kumar, N.; Pak, O.G. The effect of organizational learning on organizational commitment, job satisfaction and work performance. J. Appl. Bus. Res. 2009, 25, 55. [CrossRef]

(C) 2019 by the authors. Licensee MDPI, Basel, Switzerland. This article is an open access article distributed under the terms and conditions of the Creative Commons Attribution (CC BY) license (http://creativecommons.org/licenses/by/4.0/). 